\title{
Oral Health and Respiratory Disease- A Review
}

\author{
Aakash Shah ${ }^{1 *}$, Purvesh Shah, Santosh Kumar Goje and Romil Shah \\ Department of Orthodontics and Dentofacial Orthopedics, K.M. Shah Dental College and Hospital, India
}

Submission:March 04, 2017; Published: April 25, 2017

*Corresponding author: Dr. Aakash Shah, Post-graduate student, Department of Orthodontics and Dentofacial Orthopedics, K.M. Shah Dental College and Hospital, Vadodara, Gujarat, India; Email: Aakashshah108@gmail.com

Abstract

Recent literature supports the association between respiratory disease and oral health and confirms the oral cavity to be a harbor of infectious respiratory pathogens. Periodontal disease has been moderately associated with atherosclerosis, myocardial infarction and cardiovascular disease and the risk of chronic obstructive pulmonary disease is also known to be significantly elevated with severe periodontal attachment loss.

Keywords: Oral cavity; Respiratory diseases; Teeth

\section{Introduction}

In 2001, following a nine year study of 358 veterans, dental decay and the presence of cariogenic bacteria and periodontal pathogens were shown to be significant aspiration pneumonia risk factors [1]. Another study observed 189 elderly persons over a four year period and confirmed an association between pneumonia and decayed teeth. In this study dependence on caregivers was also linked to Pneumonia [2]. A third study linked higher plaque scores with a previous history of respiratory tract infections [3].

Pneumonia is defined as an inflammatory condition of the lung caused by bacterial, viral, fungal or parasitic infections [4]. The risk of pneumonia is, in part, determined by the specific bacteria inhaled and the body's ability to eliminate the bacteria from the airway mucosa. To eliminate aspirated bacteria from the lower airway, multiple defense mechanisms must function properly. Poor oral hygiene and the presence of periodontal disease may foster oropharyngeal colonization of respiratory pathogens which increase the probability of aspiration pneumonia, especially in high-risk patients [5]. The effectiveness of these mechanisms may also be further impaired by a variety of life conditions such as advanced age, residing in a nursing home or hospital and debilitated persons [5].

\section{Asthma Implications for Dentistry}

\section{Recognition and Understanding of Asthma}

In the dental office, the understanding of asthma is very essential. A patient with asthma symptoms may present with a need for emergency treatment. Additionally, there may be a need to use rescue medication for the patients during treatment in the dental office. It is essential to determine in advance that the rescue inhaler should always be present and easily available to the patient. The treatment side effects and symptoms of asthma should be recognized and managed appropriately. For example, side effects of asthma controller medications include oral fungal overgrowth and throat irritation. Rinsing with water should be advised to patients after each inhalation to minimize this side effect.

Additionally, there is a frequent history of asthma reported by grown-up dental patients. In children, it is more prevalent. An acute episode of asthma in the dental office may be precipitated by extrinsic factors such as inhaled allergens, as well as various intrinsic factors such as anxiety or fear. An episode of asthma should be regarded as a medical emergency and must be treated promptly by inhalation of a bronchodilating agent. The dentist should be alert with an asthma history of the dental patient and implement strategies that may prevent an acute attack and to be prepared to manage this potentially life-threatening medical emergency properly. The chronic use of glucocorticoids and/ or bronchodilating inhalers for the management of asthma can increase the likelihood of oral candidiasis, particularly in patients having other risk factors such as the use of xerostomic medications, denture use, or smoking [6].

\section{Conclusion}

The management of patient with respiratory disease in dental office is very important. Thorough diagnosis for any systemic diseases should be done for preventing any systemic 
complications during dental treatment. Various emergency drugs required in treatment of respiratory diseases should be kept in the dental office.

\section{References}

1. WHO (2015) Global tuberculosis report.

2. Colditz GA, Brewer TF, Berkey CS, Wilson ME, Burdick E, et al. (1994) Efficacy of BCG vaccine in the prevention of tuberculosis. Meta-analysis of the published literature. JAMA 271(9): 698-702.

3. Mahairas GG, Sabo PJ, Hickey MJ, Singh DC, Stover CK (1996) Molecular analysis of genetic differences between Mycobacterium bovis BCG and virulent M. bovis. J Bacteriol 178(5): 1274-1282.

4. Brosch R, Gordon SV, Garnier T, Eiglmeier K, Frigui W, et al. (2007) Genome plasticity of BCG and impact on vaccine efficacy. PNAS 104(13): 5596-5601.

5. Lagranderie MR, Balazuc AM, Deriaud E, Leclerc CD, Gheorghiu M (1996) Comparison of immune responses of mice immunized with five different Mycobacterium bovis BCG vaccine strains. Infect Immun 64(1): 1-9.

6. Castillo-Rodal AI, Castanon-Arreola M, Hernandez-Pando R, Calva JJ, Sada-Diaz E, et al. (2006) Mycobacterium bovis BCG substrains confer different levels of protection against Mycobacterium tuberculosis infection in a BALB/c model of progressive pulmonary tuberculosis. Infect Immun 74(3): 1718-1724.

7. Mangtani P, Abubakar I, Ariti C, Beynon R, Pimpin L, et al. (2014) Protection by BCG vaccine against tuberculosis: a systematic review of randomized controlled trials. Clin Infect Dis 58(4): 470-480.

8. Burl S, Adetifa UJ, Cox M, Touray E, Ota MO, et al. (2010) Delaying bacillus Calmette-Guerin vaccination from birth to $41 / 2$ months of age reduces postvaccination Th1 and IL-17 responses but leads to comparable mycobacterial responses at 9 months of age. J Immunol 185(4): 2620-2628.

9. Smith SG, Zelmer A, Blitz R, Fletcher HA, Dockrell HM (2016) Polyfunctional CD4 T-cells correlate with in vitro mycobacterial growth inhibition following Mycobacterium bovis BCG-vaccination of infants. Vaccine 34(44): 5298-5305.

10. Mendoza-Coronel E, Camacho-Sandoval R, Bonifaz LC, Lopez-Vidal Y (2011) PD-L2 induction on dendritic cells exposed to Mycobacterium avium downregulates BCG-specific $\mathrm{T}$ cell response. Tuberculosis (Edinb) 91(1): 36-46.

11. Martin Montanes C, Gicquel B (2011) New tuberculosis vaccines. Enferm Infecc Microbiol Clin 29( Suppl 1): 57-62.

12. Kaufmann SHE, Weiner J, Reyn Fv (2017) Novel approaches to tuberculosis vaccine development. Intl J Infect Dis.

13. Ahmed W, Zheng K, Liu ZF (2016) Small Non-Coding RNAs: New Insights in Modulation of Host Immune Response by Intracellular Bacterial Pathogens. Front Immunol 7: 431.

14. Maudet C, Mano M, Eulalio A (2014) MicroRNAs in the interaction between host and bacterial pathogens. FEBS Lett 588(22): 4140-4147.

15. Ma C, Li Y, Zeng J, Wu X, Liu X, et al. (2014) Mycobacterium bovis BCG triggered MyD88 induces miR-124 feedback negatively regulates immune response in alveolar epithelial cells. PLoS One 9: e92419.

16. Li M, Wang J, Fang Y, Gong S, Li M, et al. (2016) MicroRNA-146a promotes mycobacterial survival in macrophages through suppressing nitric oxide production. Sci Rep 6: 23351.

17. Pawar K, Hanisch C, Palma Vera SE, Einspanier R, Sharbati S (2016) Down regulated lncRNA MEG3 eliminates mycobacteria in macrophages via autophagy. Sci Rep 6: 19416
Your next submission with Juniper Publishers will reach you the below assets

- Quality Editorial service

- Swift Peer Review

- Reprints availability

- E-prints Service

- Manuscript Podcast for convenient understanding

- Global attainment for your research

- Manuscript accessibility in different formats

( Pdf, E-pub, Full Text, Audio)

- Unceasing customer service

Track the below URL for one-step submission https://juniperpublishers.com/online-submission.php 